\title{
Performance and wool growth in lambs fed rations containing formaldehyde treated protein
}

\section{J. Kowalczyk, Z. Buczkowski, Alina Jaczewska and Urszula Pawlus}

The Kielanowiski Institute of Animal Physiology and Nutrition, Polish Academy of Sciences, 05-110 Jablonna, Poland

(Received 15 February 1993; accepted 18 May 1993)

\section{ABSTRACT}

Thirty two 3 months old Polish Lowland wethers of about $20 \mathrm{~kg}$ initial body weight were divided into four equal groups. Wethers in each group were fed individually for 78 days with diets consisting of dried sugar beet pulp and meadow hay supplemented with untreated or formaldehyde-treated casein and untreated or formaldehyde-treated rapaseed oil meal. All diets contained about $20 \%$ crude fibre and $17 \%$ crude protein (DM basis), about $50 \%$ of that protein was derived from casein or rapeseed oil meal.

Dry mater and protein digestibility of diets containing formaldehyde treated feeds was less $(\mathrm{P}<0.05)$ and animal body weight gains were lower $(\mathrm{P}<0.01)$ than those with untreated feeds. Body gains were $20 \%$ higher in groups fed rapeseed oil meal comparing to those fed diets with casein $(P<0.01)$. Differences in length, weight and thickness of wool were not significant $(\mathrm{P}>0.05)$ between animals receiving untreated or formaldehyde-treated protein.

KEY WORDS: sheep, formaldehyde, protein, degradability, wool, performance

\section{INTRODUCTION}

Dietary protein that is protected from rumen degradation but is digestible in the small intestine of ruminant should be utilized more efficiently than unprotected protein. Ferguson et al. (1967) reported significant increases in performance and wool growth when sheep were fed formalaldehyde treated casein rations compared with untreated diets. The use of such treated protein is recommended to improve ruminant performance (Barry, 1972; Hemsley et al., 1973; Soroczyńska et al., 1986; Ćerešnáková and Sommer, 1988). In our earlier study (Kowalczyk et al., 1975) formaldehyde treatment of rapeseed oil meal protein did not improve the performance of young bulls. Langlands (1971) did 
not obtain an improvement in wool growth rate of sheep fed formaldehyde-treated cottonseed meal.

The aim of the present work was to compare the performance and wool growth in sheep fed diets containing formaldehyde-treated and untreated casein or rapeseed oil meal.

\section{MATERIAL AND METHODS}

The experiment was carried out with four groups of eight 3-months old Polish Lowland wethers of about $20 \mathrm{~kg}$ initial body weight. Wethers were kept in individual pens with free access to water and were fed twice daily on a diet consisting of dried sugar beet pulp, medow hay and a vitamin-mineral mixture supplemented with untreated $(\mathrm{U})$ or formaldehyde-treated $(\mathrm{F})$ casein $(\mathrm{C})$ or double improved rapeseed $(R)$ oil meal (groups $\mathrm{CU}, \mathrm{CF}, \mathrm{RU}$ and $\mathrm{RF}$, respectively; Table 1). The diets were formulated according to Polish standards

TABLE 1

Chemical composition of feeds. $\mathrm{g} / \mathrm{kg}$

\begin{tabular}{lccccc}
\hline Ingredients & $\begin{array}{c}\text { Dry } \\
\text { matter }\end{array}$ & Ash & $\begin{array}{c}\text { Crude } \\
\text { protein }\end{array}$ & $\begin{array}{c}\text { Ether } \\
\text { extract }\end{array}$ & $\begin{array}{c}\text { Crude } \\
\text { fibre }\end{array}$ \\
\hline Sugar beet pulp & 898.2 & 39.0 & 80.0 & 10.1 & 202.3 \\
Casein (U) & 915.1 & 24.8 & 740.0 & 6.1 & - \\
Casein (F) & 911.8 & 17.4 & 761.2 & 5.9 & - \\
Rapeseed oil meal (U) & 908.5 & 69.6 & 328.1 & 49.1 & 114.4 \\
Rapeseed oil meal (F) & 910.9 & 70.4 & 330.0 & 51.3 & 119.5 \\
Meadow hay* & 860.3 & 71.1 & 105.4 & 29.7 & 252.0 \\
\hline
\end{tabular}

* Average of 3 successive bath of hay fed to sheep

for fattening lambs and contained about $20 \%$ crude fibre and $17 \%$ crude protein (DM basis), about $50 \%$ of that protein was derived from casein or rapeseed oil meal. The level of feeding was $3.5 \%$ of body weight and was adjusted each 10 days according to changes in body weight. The animals were weighed initially, at ten day intervals and at the end of the 78 day-long experiment. Total faeces collection were made during the last 6 days of the experiment for determining nutrient digestibility.

Casein and rapeseed oil meal were treated with a $34 \%$ solution of formaldehyde ( $3.4 \mathrm{~g} \mathrm{HCHO}$ per $1 \mathrm{~kg}$ of feed protein) in plastic bags and mixed several times a day for 3 days. The product was then spread in thin layers and left in the open air for 10 days until formaldehyde odor was not longer detectable. The protein degradability of treated and untreated feed products was estimated using the in situ method of Ørskov et al. (1980) after 1, 3, 7, 12 and $24 \mathrm{~h}$ incubation in the rumen of 3 sheep fed a meadow hay: barley meal mixture (70:30). 
Daily feed intake was recorded for each individual sheep. Samples of feed refusals and faeces were analyzed for nutrient content using conventional methods (A.O.A.C., 1990). The metabolic energy of rations was calculated according to Kielanowski (1973). Sulphur content in the diets was determined by a gravimetric method (A.O.A.C., 1990). Fleece samples were sheared from a 10 $x 10 \mathrm{~cm}$ square on the shoulder at the beginning and the end of the experiment and the weight, thickness and length of the wool were estimated (I.W.T.O., 1973).

Differences between groups in the measurements taken were evaluated by factorial analysis of variance.

\section{RESULTS}

The chemical composition of all diets was similar (Table 1 and 2) but the ingested rations with casein contained slightly less crude protein $(137 \mathrm{vs} .143 \mathrm{~g} / \mathrm{kg}$

TABLE 2

Composition of daily rations, $\mathrm{g} / \mathrm{kg}$

\begin{tabular}{lcccc}
\hline \multirow{2}{*}{\multicolumn{1}{c}{ Item }} & \multicolumn{4}{c}{ Groups } \\
\cline { 2 - 5 } & CU & CF & RU & RF \\
\hline Meadow hay & 252 & 252 & 252 & 252 \\
Sugar beet pulp & 673 & 673 & 523 & 523 \\
Casein (U or F) & 75 & 75 & - & - \\
Rapeseed oil meal (U or F) & - & - & 225 & 225 \\
Dry matter & 890 & 890 & 891 & 892 \\
In kg of DM: crude protein & 153 & 155 & 159 & 160 \\
\multicolumn{1}{c}{ crude fibre } & 225 & 225 & 218 & 220 \\
\multicolumn{1}{c}{ ME, MJ } & 6.98 & 6.85 & 6.89 & 6.76 \\
\hline
\end{tabular}

of diet) than those with rapeseed oil meal (Table 5). Wethers fed casein diets consumed $3.1 \mathrm{~g} /$ day of sulphur and those fed rapeseed diets $-5.3 \mathrm{~g} /$ day; both exceeded sulphur requirements (ARC, 1980). Protein degradability of formaldehyde-treated feeds was considerably lower than that of untreated feeds (Table 3; Figure 1). Degradability pattern of untreated casein was not estimated as it was almost completely soluble after $1 \mathrm{~h}$ incubation in the rumen.

TABLE 3

Constants $a, b, c$ and SRD for casein and rapeseed oil meal protein degradability in the rumen

\begin{tabular}{lcccc}
\hline Feed & $\mathrm{d}$ & $\mathrm{b}$ & $\mathrm{c}$ & $\mathrm{RSD}$ \\
\hline Casein treated* $^{*}$ & 17.5 & 82.2 & .055 & 2.89 \\
Rapeseed oil meal untreated & 26.2 & 67.5 & .071 & 1.71 \\
Rapeseed oil meal treated & 9.5 & 86.4 & .053 & 3.78 \\
\hline
\end{tabular}

* Untreated cascin was casily dissolved (98\%) and rapidly disappeared from the bags 


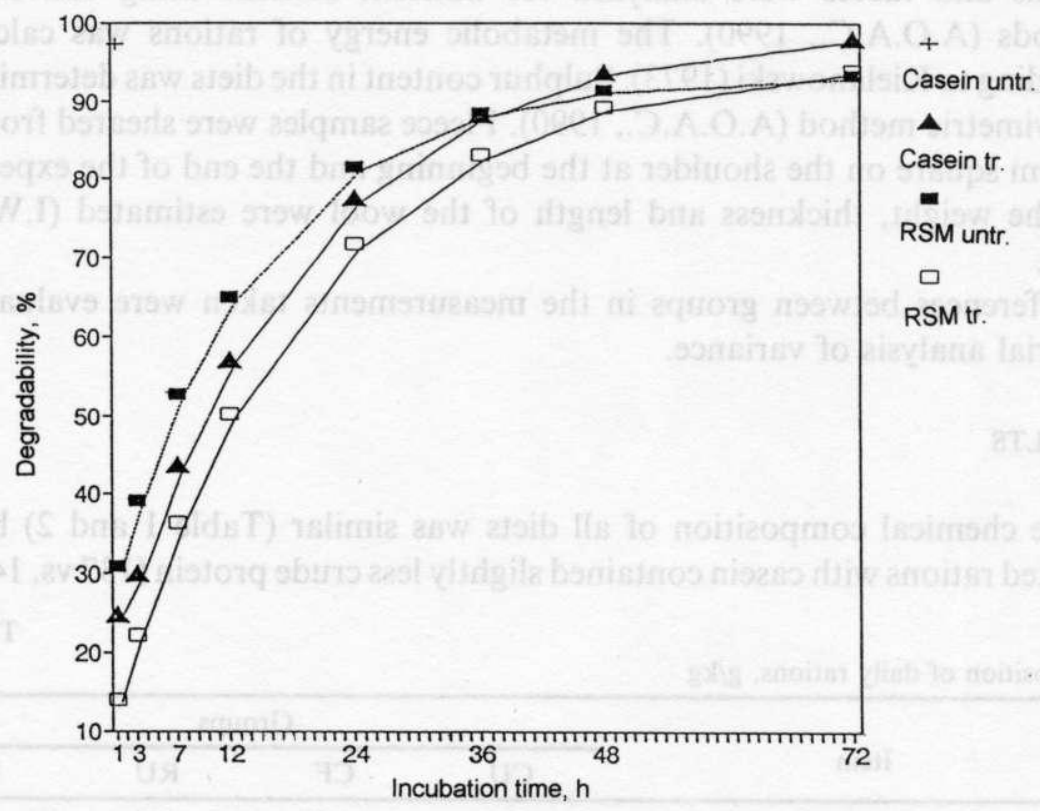

Fig. 1. Protein degradability pattern of casein and rapeseed oil meal (fitted values). Untreated casein was easily dissolved and rapidly disappeared from the bags

Apparent digestibility coefficients of dry matter, crude protein and fibre of diets containing untreated feeds were higher $(P \leqslant 0.05)$ than those containing treated feeds (Table 4). Digestibility coefficients of fat of the diets containing rapeseed oil meal were nearly twice as large as those of diets containing casein but treatment with formaldehyde did not influence fat digestibility.

TABLE 4

Apparent digestibility of nutrients, \%

Group

Item

\begin{tabular}{llll}
\hline $\mathrm{CU}$ & $\mathrm{CF}$ & $\mathrm{RU}$ & $\mathrm{RF}$
\end{tabular}

\begin{tabular}{lllll}
\hline Dry matter & $80.3 \pm 0.6^{\mathrm{a}}$ & $76.1 \pm 1.3^{\mathrm{b}}$ & $79.0 \pm 0.9^{\mathrm{a}}$ & $76.0 \pm 1.3^{\mathrm{b}}$ \\
Organic matter & $82.6 \pm 0.6$ & $81.3 \pm 1.2^{\mathrm{b}}$ & $80.3 \pm 1.4$ & $79.7 \pm 1.0$ \\
Crude protein & $72.1 \pm 0.8^{\mathrm{a}}$ & $69.3 \pm 0.6^{\mathrm{b}}$ & $71.3 \pm 0.7^{\mathrm{a}}$ & $69.5 \pm 0.8^{\mathrm{b}}$ \\
Ether extract & $22.6 \pm 3.2^{\mathrm{A}}$ & $25.8 \pm 3.2^{\mathrm{A}}$ & $47.0 \pm 1.7^{\mathrm{B}}$ & $47.9 \pm 2.4^{\mathrm{B}}$ \\
Crude fibre & $77.3 \pm 0.9^{\mathrm{a}}$ & $74.9 \pm 1.6^{\mathrm{b}}$ & $73.6 \pm 1.6^{\mathrm{bc}}$ & $70.4 \pm 2.1^{\mathrm{d}}$ \\
N-free extractives & $89.1 \pm 0.4$ & $88.0 \pm 0.8$ & $88.5 \pm 0.6$ & $87.7 \pm 0.7$ \\
\hline
\end{tabular}

Numbers with different letters differ significantly $-\mathrm{P} \leqslant 0.05$ or with capitals $-\mathrm{P} \leqslant 0.01$ 
TABLE 5

Average daily feed intake, body weight gain, feed efficiency and flece parameters $(n=8)$

\begin{tabular}{|c|c|c|c|c|}
\hline \multirow{2}{*}{ Item } & \multicolumn{4}{|c|}{ Groups } \\
\hline & $\mathrm{CU}$ & CF & RU & RF \\
\hline Initial $\mathrm{BW}, \mathrm{kg}$ & $20.9 \pm 2.9$ & $20.8 \pm 3.2$ & $20.8 \pm 3.0$ & $20.9 \pm 3.1$ \\
\hline Final BW, kg & $38.7 \pm 5.7$ & $36.8 \pm 4.2$ & $43.9 \pm 7.6$ & $42.4 \pm 4.0$ \\
\hline Daily gain, $\mathrm{g} / \mathrm{d}$ & $239 \pm 59^{\mathrm{A}}$ & $197 \pm 43^{A}$ & $277 \pm 44^{B}$ & $267 \pm 27^{\mathrm{B}}$ \\
\hline \multicolumn{5}{|l|}{ Intake: } \\
\hline dry matter, $\mathrm{kg} / \mathrm{d}$ & $1.11 \pm 0.17$ & $0.99 \pm 0.12$ & $1.19 \pm 0.22$ & $1.16 \pm 0.13$ \\
\hline crude protein, $\mathrm{g} / \mathrm{d}$ & $158 \pm 26^{\mathrm{ab}}$ & $133 \pm 20^{\mathrm{a}}$ & $191 \pm 36^{\mathrm{b}}$ & $186 \pm 21^{\mathrm{b}}$ \\
\hline $\begin{array}{l}\mathrm{CP} \text { in } \mathrm{kg} \mathrm{DM} \text { of } \\
\text { ingested feed, } \mathrm{g}\end{array}$ & 142 & 135 & 160 & 161 \\
\hline \multicolumn{5}{|c|}{ Feed efficiency $/ \mathrm{kg}$ weight gain: } \\
\hline dry matter, $\mathrm{kg}$ & $4.76 \pm 0.6$ & $5.01 \pm 0.89$ & $4.31 \pm 0.68$ & $4.34 \pm 0.43$ \\
\hline crude protein, $\mathrm{g}$ & $678 \pm 85$ & $675 \pm 105$ & $690 \pm 110$ & $697 \pm 68$ \\
\hline \multicolumn{5}{|l|}{ Fleece parameters: } \\
\hline length, $\mathrm{cm}$ & $3.3 \pm 0.4$ & $2.9 \pm 0.3$ & $3.2 \pm 0.2$ & $3.3 \pm 0.8$ \\
\hline weight, $g$ & $9.1 \pm 3.5$ & $8.5 \pm 1.0$ & $9.1 \pm 2.4$ & $9.9 \pm 4.3$ \\
\hline thickness, $\mu \mathrm{m}$ & $6.4 \pm 0.8^{\mathrm{a}}$ & $5.8 \pm 1.9^{\mathrm{a}}$ & $8.8 \pm 5.0^{\mathrm{b}}$ & $7.7 \pm 4.4^{b}$ \\
\hline
\end{tabular}

Average body weight gains were higher $(\mathrm{P} \leqslant 0.05)$ in animals fed diets with rapeseed oil meal than those fed diets with casein (Table 5). However, the differences in body gain between animals receiving formaldehyde-treated or untreated feeds were not significant $(P \geqslant 0.05)$. Wethers fed diets with cesein left refusals containing a considerable amount of casein, particularly formaldehyde-treated, while rations with rapeseed oil meal were readily eaten. Wethers fed diets with casein ingested more protein and dry matter per $\mathrm{kg}$ of body gain than those fed rapeseed oil meal diet (Table 5).

The length and weight of fleece grown during the experimental period did not differ between protein treatment and source. However, the difference in fleece thickness between the first and second shear was greater $(P \leqslant 0.01)$ for wethers fed rapeseed oil meal diets compared to casein diets, but formaldehyde treatment of both protein sources did not statistically influence fleece thickness $(P \geqslant 0.05)$.

\section{DISCUSSION}

Our results are in agreement with the findings of many experiments that have demonstrated that treatment of several protein sources with formaldehyde reduced digestibility of protein in the rumen as well as in the lower part of the digestive tract than untreated protein (MacRae et al., 1972; Sharma and Nicholson, 1975; Kowalczyk et al., 1982; Kowalczyk and Otwinowska, 1982). 
The lowered nutritive value of formaldehyde treated protein could be at result of a binding of the lysine of which content decreases during the treatment of feeds with formaldehyde (Kowalczyk et al., 1979). Smaller differences in digestibility of protein between treated and untreated feeds in this experiment in comparison with a previous experiment with cattle (Kowalczyk et al., 1975) could be explained by the relatively lower amount of formaldehyde being used for the treatment in the present study.

Fat digestibility coefficients that were twice as large for rapeseed oil meal containing diets than for casein diets can be explained by a markedly higher level of fat in rapeseed oil meal than in casein (Table 1): the amount of endogenous fat excreted in faeces in relation to the ingested fat would be much higher in wethers fed casein diets.

Body weight gains of animals were also lower in both groups receiving treated, particularly casein, feeds (Table 5). Body gains of wethers fed treated or untreated casein were lower than those fed rapeseed oil meal diets which could be aused by the lower dry matter and protein intake in groups fed casein, or lower nutritive value of diets with casein since feed efficiency was better for rapeseed oil meal containing diets.

Several authors (Ferguson et al., 1967; Langlands, 1971; Barry, 1972; Hemsley et al.. 1973; Soroc7yńska et al., 1986) have reported improved wool growth for sheep fed formaldehyde-treated feeds. To the contrary, our results agree with other authors who report that formaldehyde-treated protein fed to sheep did not stimulate the wool growth (Langlands, 1971b; 1973: Syrjala, 1976: Barry and Andrews. 1973; Sandev et al., 1976; Singh et al.. 1980). Possible explanations for the different responses reason for formaldehyde treatment of protein on wool growth could lie in the different experimental conditions, diet composition or the method of treatment as well as the level of formaldehyde used for treatment (Hemsley et al., 1973). The relatively high level of crude protein in the diets could have decreased the effect of formaldehyde treatment on animal performance results since control diets containing untreated protein met the requirement of animals for nitrogen and sulphur. The results of our experiment do not substantiate that the treatment of feed protein with formaldehyde wili improve performance and wool growth when feeding sheep according to Polish standards.

\section{REFERENCES}

A.O.A C.. 1990. Ollicial methods of analysis. Arlington A.R.C.. 1980. The Nurtient Requirements of Ruminant Livestock. CAB Farnhan Royal, Slough

Barry T.N., 1972. The effect of feeding formaldehyde-treated cascin to sheep on nitrogen retention and wool growth. N.Z. J. Agric. Res. 15, 107-116

Barry T.N., Andrew R.N.. 1973. Content and retention of sulphur in wool as affected by 
formaldehyde treatment of the diet, level of energy intake, and intraperitoneal supplementation with DL-methionine. N.Z. J. Agric. Res. 16, 545-550

Čeresňáková Z., Sommer A., 1988. Vplyv chemického a fizykálnego ošetrenia bielkovinovych krmiv na ich vyuzitiel'nost' vo vyżive preżuvavcov. Pol'nohospodarstvo Ser. A, 1/88

Ferguson K.A., Hemsley J.A., Reis P.J., 1967. Nutrition and wool growth. The effect of protecting dietary protein from microbial degradation in the rumen. Aust. J. Sci. 30, 215-217

Hemsley J.A., Reis P.J., Downes A.M., 1973. Influence of various formaldehyde treatments on the nutritional value of casein for wool growth. Aust. J. Biol. Sci. 26, 961-972

I.W.T.O., 1973. Metoda wyznaczania średniej średnicy włókien w taśmie czesankowej przy pomocy aparatu AIR-FLOW. I.W.T.0., Paryż

Kielanowski J., 1973. Energetyczne wartościowanie pasz. PWRiL, Warszawa

Kowalczyk J., Chomyszyn M., Otwinowska A., 1975. Nutritive value of formaldehyde treated rapeseed oil meal for young cattle. Rocz. Nauk rol., Ser. B 96, 21-32

Kowalczyk J., Jaczewska A., Morawiec M., 1979. Digestion in vitro of protein of feeds treated with different amounts of formaldehyde. Rocz. Nauk rol., Ser. B 99, 53-63

Kowalczyk J., Otwinowska A., 1982. Digestion of formaldehyde treated rapeseed protein in the intestinal tract of young bulls. Arch. Tierernähr. 32, 755-761

Kowalczyk J., Robinson J.J., Otwinowska A., 1982. Digestion in the small intestine of young bulls of the protein of rapeseed meal treated or untreated with formaldehyde. Anim. Feed Sci. Tech. 7, $225-232$

Langlands J.P., 1971a. The wool production of grazing sheep supplemented with casein and formaldehyde-treated casein. Aust. J. exp. Agric. Anim. Husb. 11, 9-13

Langlands J.P., 1971b. The wool production of sheep supplemented with cottonseed meal and formaldehyde-treated cottonseed meal. Aust. J. exp. Agric. Anim. Husb. 11, 493-497

Langlands J.P., 1973. Wheat as survival ration for sheep. 2. The effect of frequency of feeding and formaldehyde treatment on wool production and live weight change. Aust. J. exp. Agric. Anim. Husb. 13, 347-350

MacRae J.C., Ulyatt D.A., Pearce P.D., Hendtlass J., 1972. Quantitative intestinal digestion of nitrogen in sheep given formaldehyde-treated casein supplements. Br. J. Nutr. 27, 39-50

Ørskov E.R., Hovel F.D.DeB, 1980. The use of the nylon bag technique for the evaluation of feedstuffs. Tropical Anim. Prod. 5, 195-213

Sandev S., Stojanov A., Dardjonov T., 1976. Untersuchungen zum Einzats von formalinbehandeltem Sonnenblumenextraktionschrot und Methioninhydroxyanalog in Rationen für hochproduktive Schafe. Arch. Tierernähr. 26, 637-642

Sharma H.L., Nicholson J.W.G., 1975. Nitrogen metabolism and flow of nitrogenous compounds through the gastrointestinal tract of sheep fed formaldehyde-treated rapeseed meal. Can. J. Anim. Sci. 55, 697-703

Singh N.P., Rai A.K., Ratan R., Patnayak B.C., 1980. Influence of formaldehyde treated proteins in sheep. 2. Effect of liveweight gain, wool production and nutrient digestibility in lambs. Indian Vet. J. 57, 339-341

Soroczyńska M., Kulasek G., Jędrzejewska H., 1986. Urea as substitute of protein in feeding of sheep. Zesz. probl. Post. Nauk rol. 303, 373-380

Syrjala L., 1976. Live-weight gain, feed intake and wool growth of lambs on different grass silages and sucrose and starch supplements. Ann. Agric. Fenn. 14, 338-340

\section{STRESZCZENIE}

\section{Przyrosty masy ciala i wełny u owiec żywionych dawkami z paszami nietraktowanymi lub traktowanymi formaldehydem}

Trzydzieści dwa trzy - miesięczne tryczki polskiej owcy nizinnej o początkowej masie ciała $20 \mathrm{~kg}$ podzielono na 4 grupy, po 8 sztuk w każdej. Jagnięta żywiono indywidualnie 
przez 78 dni dawkami zawierającymi wysłodki buraczane i siano łąkowe uzupełnione odpowiednio kazeiną zwykłą (grupa UC) lub formaldehydowaną $(\mathrm{FC})$, poekstrakcyjną śrutą z rzepaku OO zwykłą (grupa RU) lub traktowaną formaldehydem (RF). Wszystkie dawki zawierały około $20 \%$ włókna surowego i $17 \%$ białka ogólnego w suchej masie. Połowa zawartości białka w dawkach pochodziła z kazeiny bądź śruty rzepakowej.

Sucha masa i białko dawek zawierających pasze formaldehydowane były gorzej trawione $(\mathrm{P}<0.05)$, a przyrosty masy ciała zwierząt były niższe $(\mathrm{P}<0.01)$ niż przy skarmianiu pasz zwykłych. Przyrosty masy ciała zwierząt otrzymujących śrutę rzepakową były o około $20 \%$ większe niż otrzymujących kazeinę $(\mathrm{P}<0.01)$. Przyrost wełny — długość włókien, masa i grubość nie różniły się między grupami jagniąt żywionych paszami zwykłymi bądź traktowanymi formaldehydem $(\mathrm{P}>0.05)$. 